\title{
Closed reduction with minimal accesses for treating isolated zygomatic arch
}

\section{fractures: Case Series}

\section{Redução fechadla com acessos mínimos para tratamento de fraturas isoladas de arco zigomático:}

Série de casos

Reducción cerrada con mínimos accesos para el tratamiento de fracturas aisladas del arco cigomático: Series de casos

\begin{abstract}
Following nasal fractures, zygomatic fractures (ZF) are the second most prevalent of maxillofacial fractures. Isolated fractures of the zygomatic arch (IZAF) are rare, corresponding to less than $10 \%$ of all fractures involving the zygomaticmaxillary complex (ZMC). The choice of treatment for IZAF is controversial, and there is no defined consensus in the literature. We seek to evaluate the advantages of closed reductions with minimal accesses over open reductions through a case series and a 10-year literature review. All patients in our study obtained a satisfactory final result in terms of aesthetics and function of the zygomatic arch, with no complications involved. There are criteria established in the current literature on the indication of open surgery or closed reduction. Open reduction with rigid fixation has the most significant number of studies proving its clinical efficacy. However, closed reduction with minimal accesses has proven to be a suitable therapeutic option for IZAF, presenting satisfactory aesthetic results and fewer surgical risks.
\end{abstract}

Keywords: Zygoma; Zygomatic fractures; Closed fracture reduction; Minimally invasive surgical procedures.

\section{Resumo}

Depois das fraturas nasais, as fraturas zigomáticas (ZF) são a segunda mais prevalente das fraturas maxilofaciais. As fraturas isoladas do arco zigomático (IZAF) são raras, correspondendo a menos de $10 \%$ de todas as fraturas envolvendo o complexo zigomático-maxilar (ZMC). A escolha do tratamento para IZAF é controversa e não há consenso definido 
na literatura. Procuramos avaliar as vantagens das reduções fechadas com acessos mínimos sobre as reduções abertas por meio de uma série de casos e uma revisão da literatura de 10 anos. Todos os pacientes do nosso estudo obtiveram resultado final satisfatório do ponto de vista estético e funcional do arco zigomático, sem complicações. Existem critérios estabelecidos na literatura atual sobre a indicação de cirurgia aberta ou redução incruenta. A redução aberta com fixação rígida possui o número mais significativo de estudos que comprovam sua eficácia clínica. No entanto, a redução incruenta com acessos mínimos tem se mostrado uma opção terapêutica adequada para IZAF, apresentando resultados estéticos satisfatórios e menores riscos cirúrgicos.

Palavras-chave: Zigoma; Fraturas zigomáticas; Redução fechada; Procedimentos cirúrgicos minimamente invasivos.

\section{Resumen}

Después de las fracturas nasales, las fracturas cigomáticas (ZF) son las segundas más prevalentes de las fracturas maxilofaciales. Las fracturas aisladas del arco cigomático (IZAF) son raras y corresponden a menos del $10 \%$ de todas las fracturas que involucran el complejo cigomático-maxilar (ZMC). La elección del tratamiento para IZAF es controvertida y no existe un consenso definido en la literatura. Buscamos evaluar las ventajas de las reducciones cerradas con acceso mínimo sobre las reducciones abiertas a través de una serie de casos y una revisión de la literatura de 10 años. Todos los pacientes de nuestro estudio obtuvieron un resultado final satisfactorio desde el punto de vista estético y funcional del arco cigomático, sin complicaciones. Existen criterios establecidos en la literatura actual sobre la indicación de cirugía abierta o reducción cerrada. La reducción abierta con fijación rígida tiene el número más significativo de estudios que demuestran su eficacia clínica. Sin embargo, la reducción cerrada con mínimo acceso ha demostrado ser una opción terapéutica adecuada para IZAF, presentando resultados estéticos satisfactorios y menores riesgos quirúrgicos.

Palabras clave: Cigoma; Fracturas cigomáticas; Reducción cerrada; Procedimientos quirúrgicos mínimamente invasivos.

\section{Introduction}

The zygomatic arch (ZA) is part of the zygomatic complex (ZC) and plays an essential role in the facial contour, specifically in the lateral projection. Its bony architecture maintains the midface stabilization and supports the normal masticatory load (Xie et al., 2009). The ZC is the third most commonly fractured facial area; however, isolated zygomatic arch fractures (IZAF) are rare, representing only 5-10\% of ZC injuries reported in the literature (Adam et al., 2012; Yoon et al., 2014).

Disruption of the ZA position can affect the facial skeleton's structural, functional, and aesthetic appearances. Therefore, IZAF has to be appropriately diagnosed and treated for cosmetic and functional reasons (Ji et al., 2016; Ravi Raja Kumar et al., 2010).

The most related symptoms are pain, swelling, difficulty in mouth opening, and zygomatic arch sensitiveness on physical examination. Radiographic and tomographic images can be used to confirm IZAF diagnosis. The submentovertex is the radiographic view indicated to analyze the zygomatic arch symmetry. Computed tomography should be carefully considered for IZAF assessment because of its high radiation exposure and high cost (Kim et al., 2016; Korkmaz et al., 2016).

IZAF is mainly caused by road traffic accidents, falls, sports-related injuries, and civilian warfares. These injuries predominantly occur in male patients from the second to the third decade of life (Yamsani et al., 2016).

Management of IZAF must be accurate because improper ZA reductions may result in facial asymmetry and mastication disability (Ahn et al., 2015). Variable methods have been introduced for the treatment of IZAF. Occasionally, open reduction and rigid fixation are required for zygomatic arches fractured in several segments or grossly displaced (Prakasam et al., 2010). However, open operations carry possible complications, such as facial nerve injuries, unsatisfactory scarring, and hemorrhages (Xie et al., 2009).

The treatment of IZAF depends mainly on the degree of displacement. Nevertheless, closed reductions are the preferred method in order to avoid post-surgical complications. There are several techniques for indirect ZA reductions like Gille's temporal, Bala Subrahmaniam upper buccal sulcus, Quinn's, Keen's lateral coronoid, and percutaneous approaches (Ravi Raja Kumar et al., 2010).

This study aimed to describe a series of 10 cases of IZAF treated with closed reductions through minimal percutaneous 
access and discuss the most appropriate choice of treatment according to a 10-year literature review.

\section{Methodology}

A retrospective study was carried out involving male and female patients of any age with isolated zygomatic arch fractures. The sample was determined by spontaneous demand at the emergency ward of a northeastern Brazilian hospital between January 2020 and January 2021 (1 year). After the treatment of each case, data were gathered, and a review of literature on this topic was also performed. The criteria used for the study of this case series relate to the qualitative, quantitative, and observational methods. Our sample of 10 cases was the quantitative factor, and the clinical signs and symptoms were the qualitative features. Therefore, a quali-quantitative analysis was followed along with a 10-year literature review for a detailed discussion on the selected cases (Pereira et al., 2018). This study was legally supported by Helsinki Declaration guidelines and patients' informed consent forms.

\section{Results and Cases Presentation}

Ten patients diagnosed with isolated zygomatic arch fractures from January 2020 and January 2021 are listed in Table 1. Their age ranged from 18 to 47. The ratio of males:females was 9:1 (nine males and one female). There were six cases of left zygomatic arch injuries and four on the right side. The occurrences of IZAF were prevalent in the second semester of the year 2020. Due to the social isolation established by the pandemic situation (Covid-19), lockdown's flexibilizations started only in July 2020 in Pernambuco, Brazil. Therefore, July shows the highest number of IZAF cases (6), following the logic of the scenario.

Depending on the zygomatic arch displacement level, clinical signs, cosmetic issues, access, and dental instruments were selected according to each case to provide the proper closed reduction to the IZAF. Supraorbital eyebrow percutaneous approaches were chosen for $70 \%$ of IZAF cases, and zygomatic arch body accesses were used only in $30 \%$ of patients. A molt periosteal elevator and a Barros hook were the two selected instruments for the closed reduction technique (Table 1).

The etiological factors (Graphic 1) of the studied cases were mainly road traffic accidents, involving specifically motorcycles (50\%), followed by fall (20\%), sports-related injuries (20\%), and lastly, physical aggression (10\%).

Among the ten patients, the most related clinical features and symptoms (Graphic 2) were pain (100\%), swelling (60\%), reduced mouth opening (40\%), and mastication disability (40\%).

Table 1. Summary of patients.

\begin{tabular}{|c|c|c|c|c|c|c|c|}
\hline Case & Gender & Etiology & Age & Diagnostic & Access & Instrument & Month/year \\
\hline 1 & Male & Motorcycle accident & 36 & Isolated left zygomatic arch fracture & Supraorbital eyebrow percutaneous approach & Molt periosteal elevator & april/20 \\
\hline 2 & Male & Motorcycle accident & 36 & Isolated left zygomatic arch fracture & Zygomatic arch body percutaneous approach & Barros' hook & july/20 \\
\hline 3 & Male & Physical aggression & 18 & Isolated left zygomatic arch fracture & Zygomatic arch body percutaneous approach & Barros' hook & july $/ 20$ \\
\hline 4 & Male & Fall & 46 & Isolated left zygomatic arch fracture & Supraorbital eyebrow percutaneous approach & Molt periosteal elevator & july/20 \\
\hline 5 & Male & Sports-related injury & 21 & Isolated right zygomatic arch fracture & Supraorbital eyebrow percutaneous approach & Molt periosteal elevator & july/20 \\
\hline 6 & Male & Motorcycle accident & 19 & Isolated right zygomatic arch fracture & Supraorbital eyebrow percutaneous approach & Molt periosteal elevator & july/20 \\
\hline 7 & Male & Motorcycle accident & 27 & Isolated right zygomatic arch fracture & Zygomatic arch body percutaneous approach & Barros' hook & july $/ 20$ \\
\hline 8 & Male & Sports-related injury & 32 & Isolated left zygomatic arch fracture & Supraorbital eyebrow percutaneous approach & Molt periosteal elevator & august/20 \\
\hline 9 & Female & Fall & 47 & Isolated left zygomatic arch fracture & Supraorbital eyebrow percutaneous approach & Molt periosteal elevator & october $/ 20$ \\
\hline 10 & Male & Motorcycle accident & 32 & Isolated right zygomatic arch fracture & Supraorbital eyebrow percutaneous approach & Molt periosteal elevator & november/20 \\
\hline
\end{tabular}

Source: Personal archive. 
Graphic 1. Etiological prevalence of the IZAF ten cases.

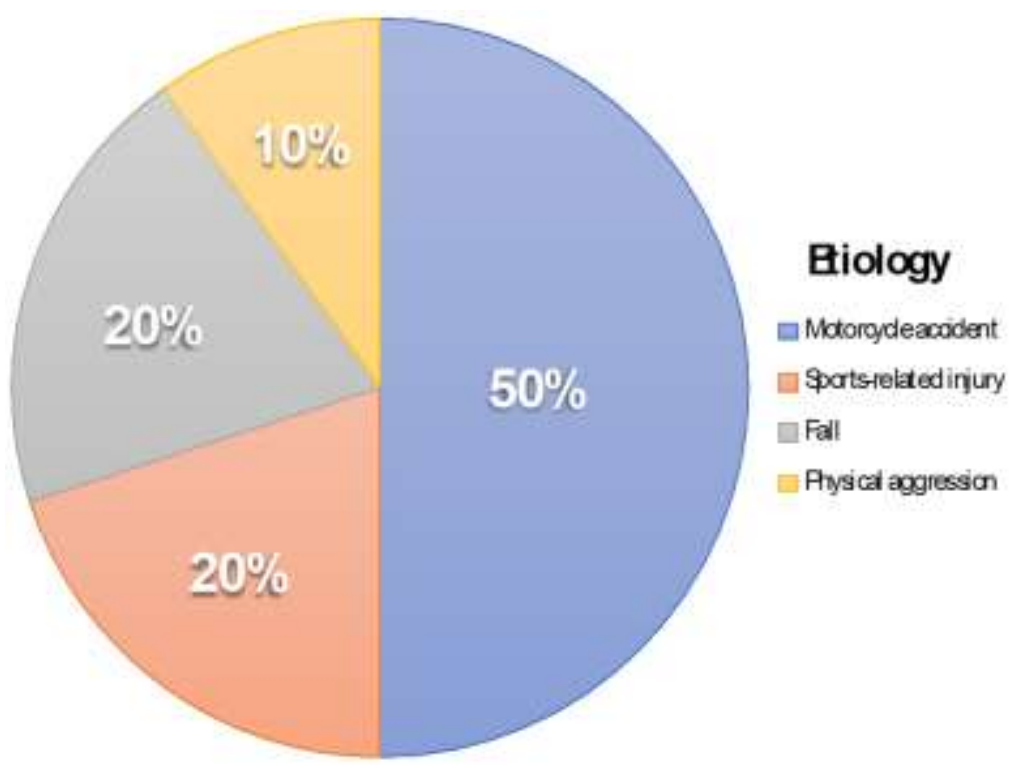

Source: Personal archive.

Graphic 2. Most reported clinical features and symptoms of the IZAF ten cases.

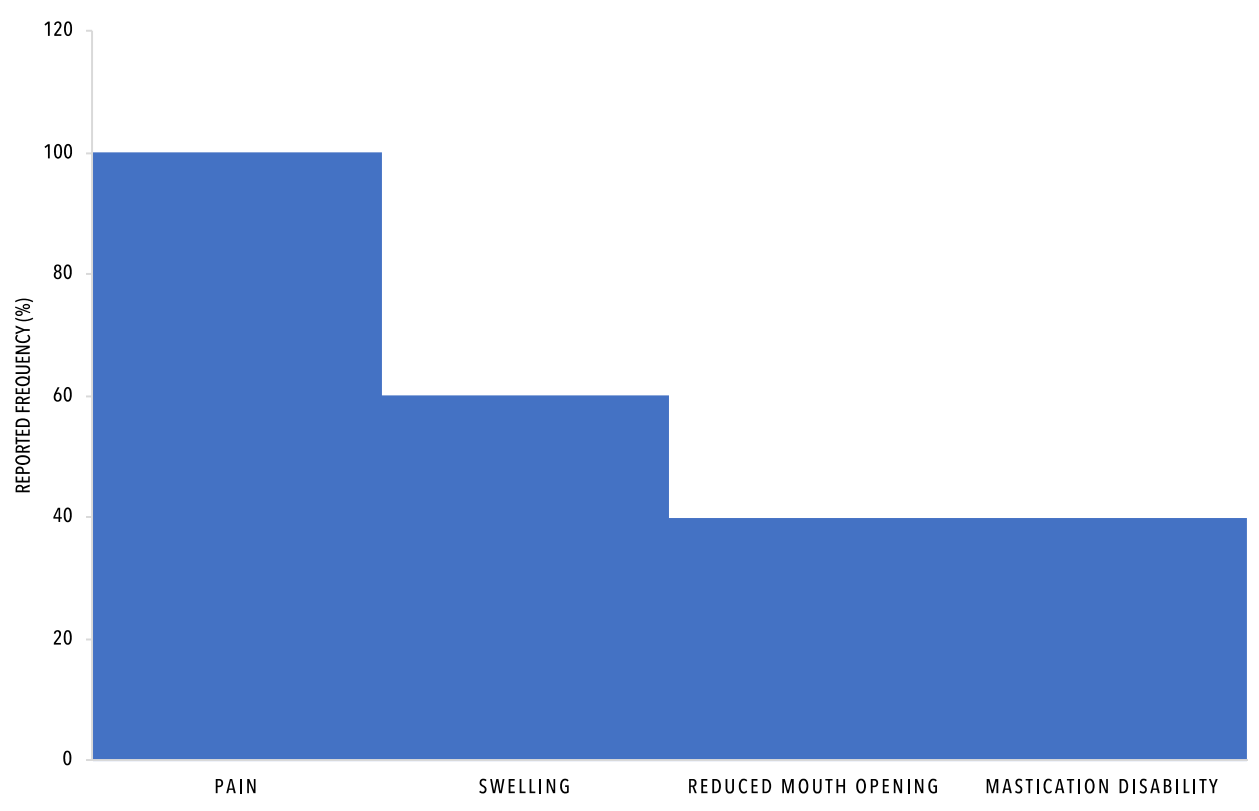

Source: Personal archive.

The present case series included ten patients diagnosed with isolated zygomatic arch fractures treated by closed reduction and minimally invasive percutaneous access. All ten patients underwent a detailed clinical examination, routine hematological pre-operative investigations, and imaginological exams (Figure 1). None of them had any history of known systemic illness or drug allergies. In all cases, an evident clinical sign was the depression of the zygomatic arch, presenting itself through an asymmetric facial lateral contour (Figure 2). 
Figure 1. CT and radiographic in axial views showing isolated zygomatic arch fractures; A) Right affected site B)Left affected site.

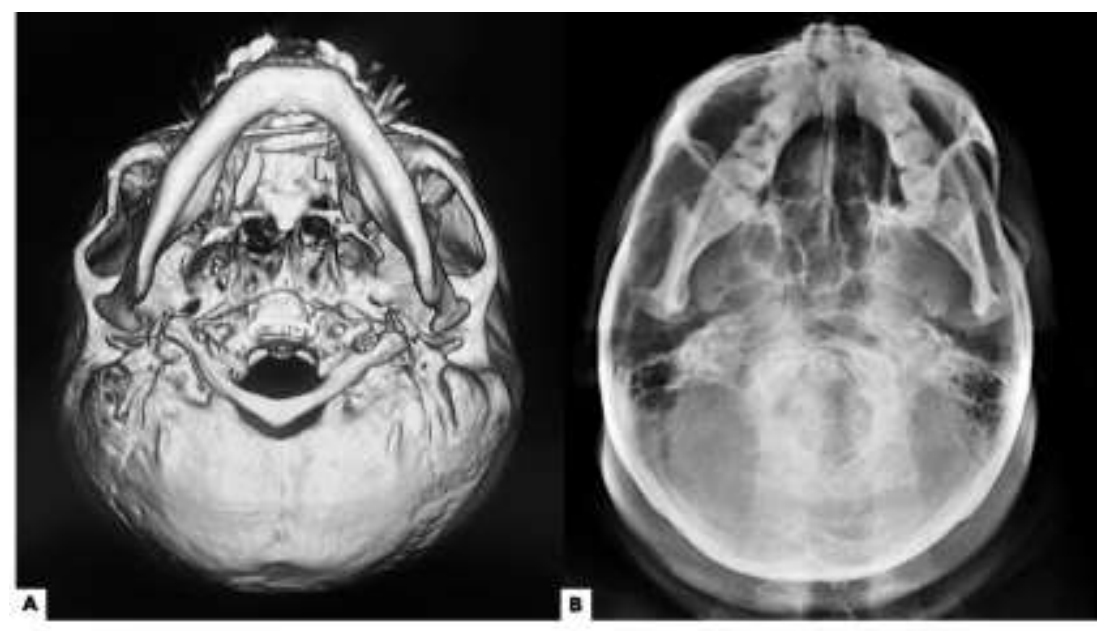

Source: Personal archive.

After clinical assessment, treatment options were established according to the patient's collaboration, clinical features, and aesthetic reasons. Patients with high pain levels were submitted to surgical procedures under sedation or general anesthesia. Patients with minor clinical complaints were submitted to surgical treatment with local anesthesia. $60 \%$ of the cases had a more extended hospital stay because they needed intravenous medication with corticosteroids before treatment to reduce edema. Immediate treatments were performed only in patients without swelling (40\%) to restore the appropriate facial contour and compare it to the contralateral side. 
Research, Society and Development, v. 10, n. 6, e30810615792, 2021

(CC BY 4.0) | ISSN 2525-3409 | DOI: http://dx.doi.org/10.33448/rsd-v10i6.15792

Figure 2. The pre-operative aspect of right (A) and left (B) depressed zygomatic arches.

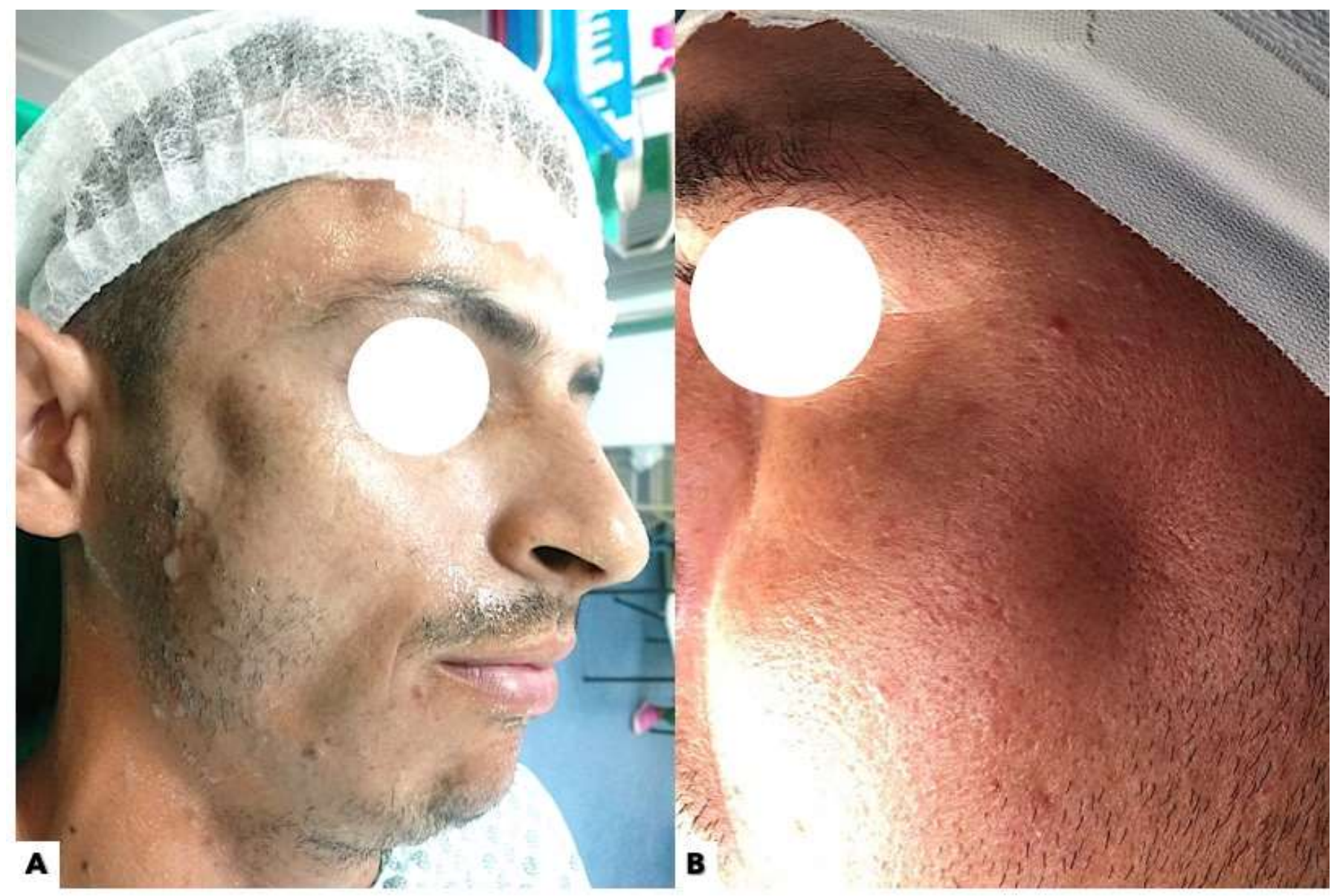

Source: Personal archive.

Most of the cases were conducted under sedation and with the aid of local anesthesia. Supraorbital eyebrow percutaneous access was convenient for most closed IZAF reductions. An approximately $0,5-1 \mathrm{~cm}$ long horizontal incision (to the minor extent possible, just enough to insert the instrument) was made parallel to the eyebrow hair follicles. These accesses allow a straight path to the zygomatic arch. Molt periosteal elevators have a vertical shape that facilitates reduction by this route. Closed IZAF reductions with Barros' hook were made through minimal extended $(0.2-0.5 \mathrm{~cm})$ percutaneous accesses in the body of the zygomatic arch. The location of this access allows a lateral hook reduction since the instrument's active tip fits right under the depressed arch (Figure 3). 
Figure 3. Barros' bone hook was placed beneath the malar prominence for the closed reduction.

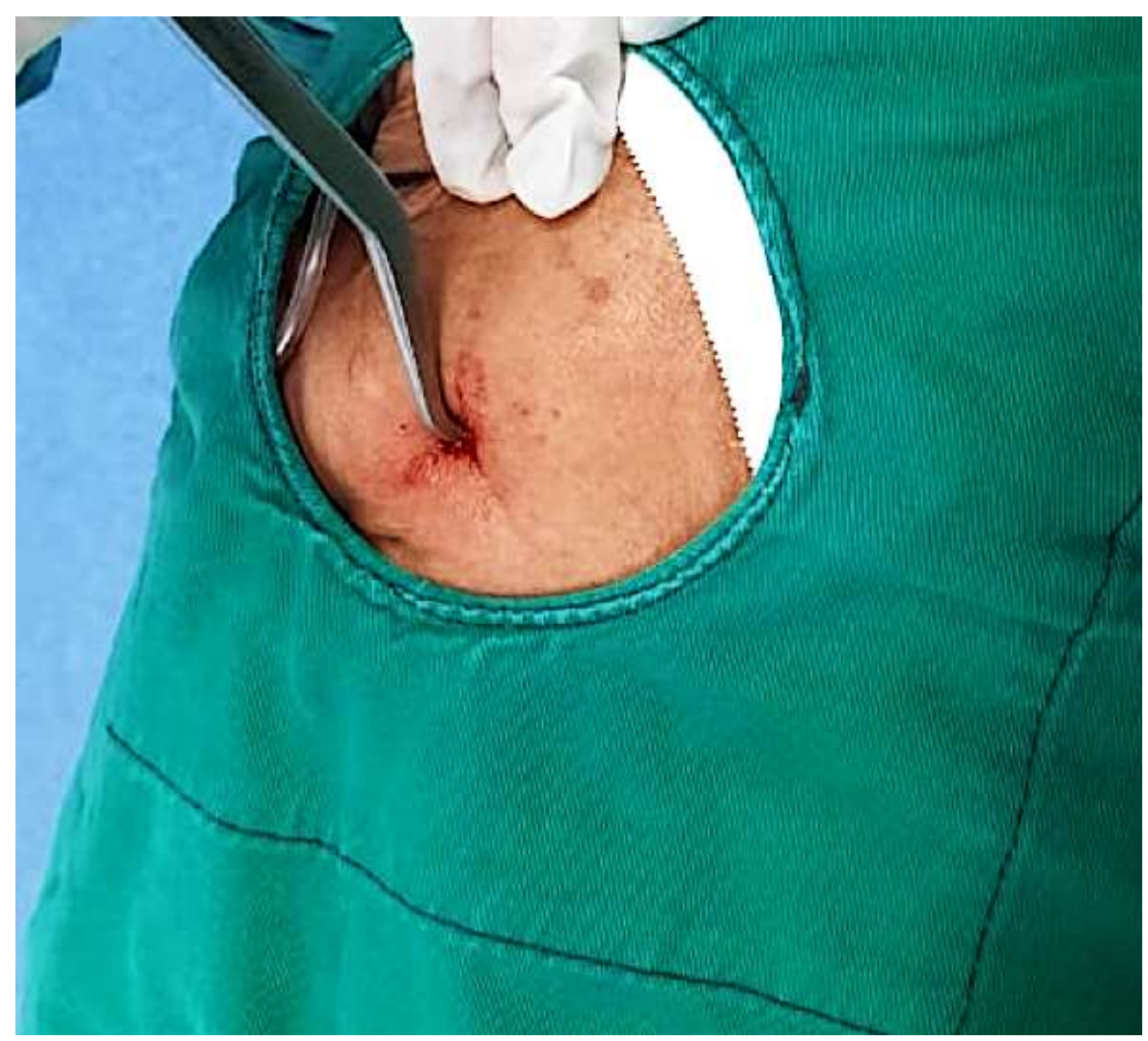

Source: Personal archive.

The zygomatic lateral projection was reestablished immediately after closed reductions (Figure 4). A new imaging test was requested to certify the correct position of the zygomatic arch (Figure 5). The most commonly requested exams were axial radiographic views. CT scans were only preferred when other facial fractures were suspected.

All ten patients were followed up on an outpatient basis for about three months. There were no reports of clinical complaints or masticatory dysfunctions. Patients followed postoperative recommendations (pasty diet, thermotherapy after cryotherapy, avoid trauma to the operated region). Analgesic and anti-inflammatory medications were prescribed according to each surgical procedure. All closed IZAF reductions ended without complications. Post-surgical home care was strongly advised, mainly about not pressing the operating region to avoid new ZA depression. Patients were satisfied with both aesthetic and functional factors. 
Research, Society and Development, v. 10, n. 6, e30810615792, 2021

(CC BY 4.0) | ISSN 2525-3409 | DOI: http://dx.doi.org/10.33448/rsd-v10i6.15792

Figure 4. Clinical presentation in the immediate postoperative moment. The lateral zygomatic projection was restored satisfactorily after IZAF reductions with molt elevators and minimal eyebrow access.

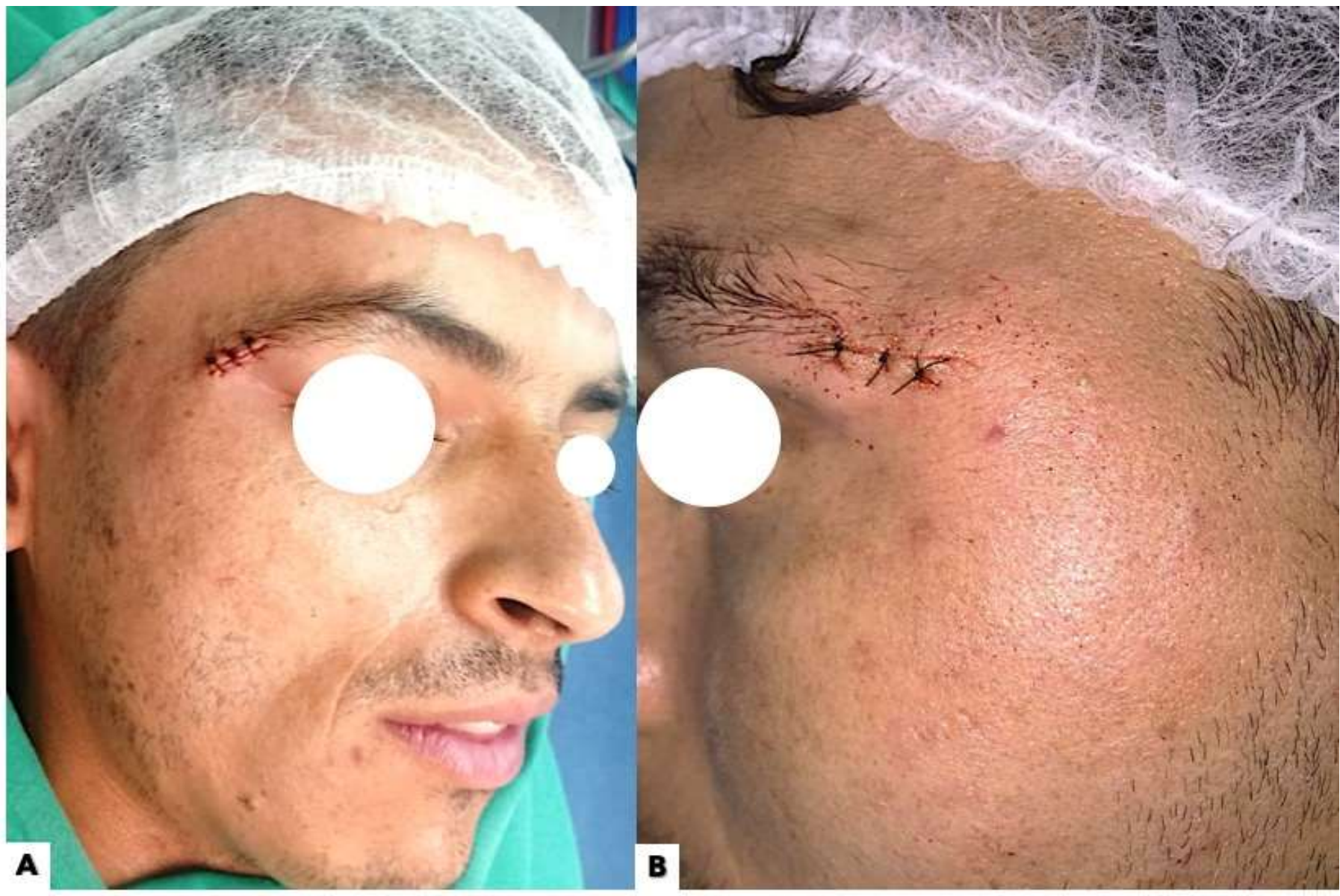

Source: Personal archive. 
Figure 5. Radiographic exam showing an adequate left zygomatic arch reduction.

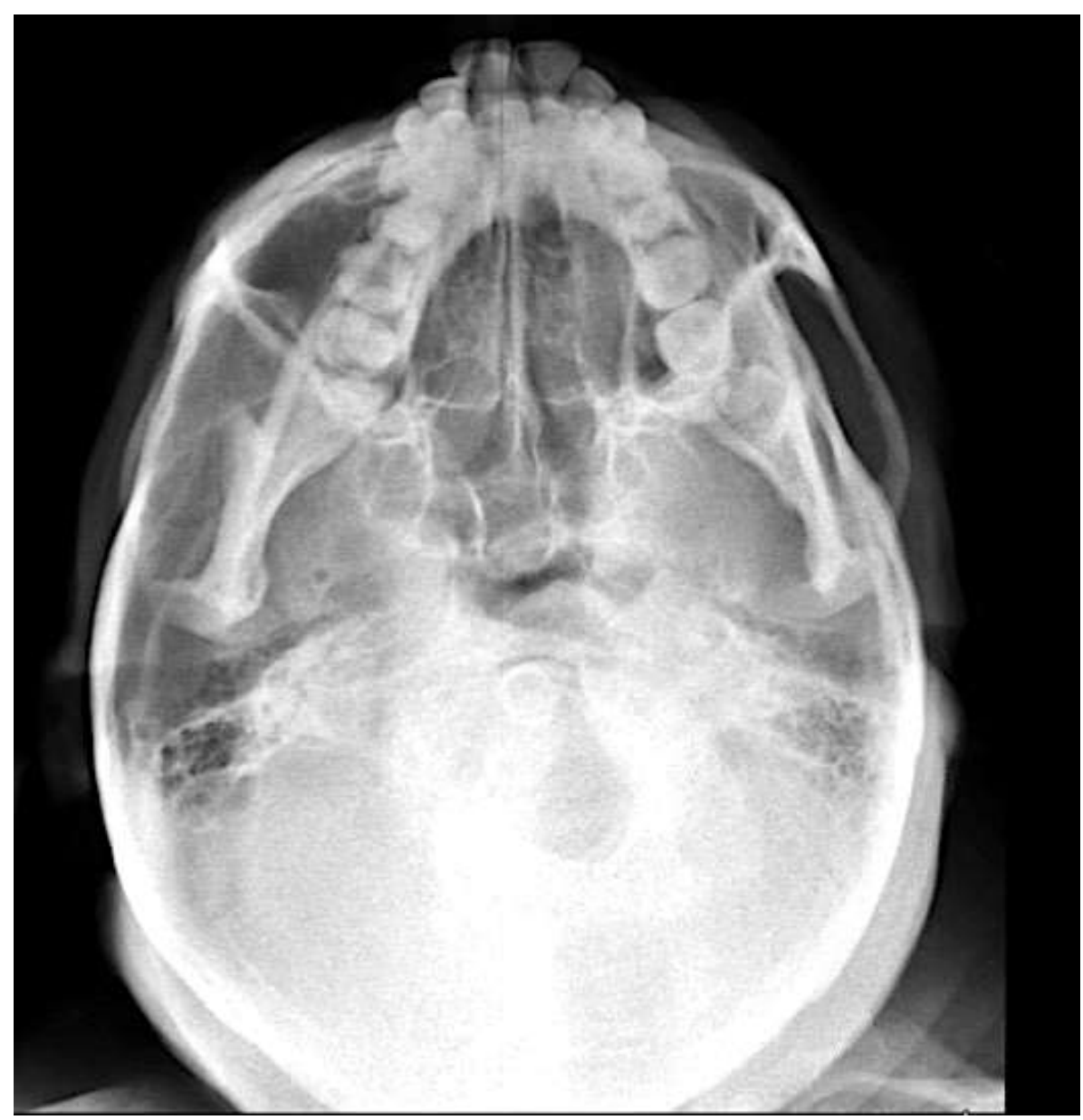

Source: Personal archive.

\section{Discussion}

The zygomatic complex (ZC) is a crucial component of the midface. Its position maintains the anteroposterior projection and facial contour. Due to its protruded shape, this bone is vulnerable to injuries, and zygomatic fractures (ZF) are considered the second most common facial fracture type. Following nasal fractures, ZF represents $13 \%$ of all maxillofacial fractures (Cinal et al., 2019). The zygomatic arch makes up for the anterior-lateral part of ZC. However, isolated zygomatic arch fractures (IZAF) are rare and comprise only $10 \%$ of all ZF and 5\% of all facial bone fractures (Yoon et al., 2014).

IZAF commonly results in a $\mathrm{V}$-shaped indentation of the lateral aspect of the face, a noticeable depression at the fracture site. Also, patients often relate limited mouth opening, possibly because of the zygomatic arch's impingement with the coronoid process (Ravi Raja Kumar et al., 2010). Other symptoms and clinical features reported by the literature and observed in our case series were swelling, pain, and mastication disability (Prakasam et al., 2010).

There are geographic and sociodemographic aspects in the epidemiology of craniofacial fractures. In our study, the etiological factors involving IZAF were road traffic accidents, falls, sports injuries, and violent aggressions, in agreement with the data found in the literature (Starch-Jensen et al., 2018). Traffic accidents were not prevalent only in studies conducted in places where safety measures, such as helmets and seat belts, are strictly followed. In another survey conducted at our institution on motorcycle accidents, it was concluded that helmet use leads to a lower number of fractures and severity of trauma compared to nonuse (Cavalcante et al., 2021; Yamsani et al., 2016). 
The gender associated with this type of trauma was mainly male above female (in a 9:1 ratio), another similar finding from several reports (Rohit et al., 2021). The age group of our study also relies upon the studies mentioned by Yamsani et al., who found out that $80 \%$ of Nigerian patients with ZF were between 21 and 40 years (Yamsani et al., 2016).

Surgical restoration of lateral facial projection can be a challenge with IZAF because there are controversies regarding open or closed reduction. Usually, closed reductions are the most suitable treatment choice. However, some authors report the need for open surgery and rigid fixation in cases of IZAF with more than two fracture lines, very dislocated zygomatic arches, or combined fractures (Jang et al., 2021; Jardim et al., 2013). The clinical cases included in this study corroborate these data, as there are included only classic zygomatic arch fractures, totally isolated, with no other bone structures compromised.

IZAF with intact periosteum and minimal displacement may be repositioned via limited incisions. Many devices have been suggested for stable closed reductions, including bone hooks, molt periosteal elevators, and Kirschner wires (Strong \& Gary, 2017). It is crucial to select adequate access and instrument to avoid improper zygomatic arch reductions and prevent instability, malunion, or asymmetry (Korkmaz et al., 2016).

Up to now, several approaches have been introduced for the closed reduction of IZAF. The most popular ones are Gillies' temporal technique, Keen's intra-oral access, percutaneous incision, and lateral eyebrow approach (Camilleri et al., 2005). Open surgery provides extended access and direct visualization of the fracture site. However, large incisions and wide dissections can increase operative time and the risk of post-surgical complications (Ji et al., 2016). These invasive approaches may result in massive bleeding, scarring, persistent edema, and numbness (Cheon et al., 2013).

The traditional closed reduction for IZAF can be achieved with digital palpation alone. However, this technique requires considerable skills on the surgeon's part to reduce an uneven and curved bone properly (Kim et al., 2016; Xie et al., 2009). Twelve different surgeons carried out a study of closed reduction with percutaneous transfacial Kirschner wire fixation (CRWF), most of them being junior surgeons with limited experience regarding the CRWF technique. It was assumed that the main clinical criteria to evaluate the quality of IZAF's closed reduction is facial symmetry by comparing the affected side to the healthy side (Giran et al., 2019).

Nevertheless, the closed reduction using traction instruments has proven to be undemanding such that training residents often perform these methods without complications, as applied in our study. Also, the instruments used for this reduction are widespread items, readily available at any maxillofacial surgery service, and very familiar to all surgeons in this field. Even though it is not a novel treatment, it is a low-cost and fast execution option, which mainly benefits the patient, avoiding late treatments (Ahn et al., 2015).

In our case series, minimal extraoral accesses for the closed reductions were adequate for all IZAF. Lateral eyebrow and percutaneous incisions were the two selected approaches for our study. Minimally invasive surgical procedures have shown satisfactory results in the literature. A Lever technique employed by Cinal et al. has proved that minimal access approaches are safe to perform, easy to learn, fast to apply, simple to conduct, and provides successful reduction (Cinal et al., 2019).

Closed reductions are still the least used techniques in the literature, hardly reaching the $10 \%$ mark when compared to open reductions (Adam et al., 2012; Strong \& Gary, 2017). However, our case series included patients with low-velocity injuries resulting in IZAF, which are good candidates for closed reduction. All patients had early fracture repairs with stables reductions and satisfactory cosmetic results.

\section{Conclusion}

There is no consensus in the literature regarding the best treatment for zygomatic fractures, especially isolated zygomatic arch fractures (IZAF), which are rare. Following the most current literature, IZAF with moderate displacement and without bone fragmentation can be managed conservatively. The lack of dynamic actions in the zygomatic arch facilitates closed reduction 
approaches without the need for immobilization or fixation. Early treatments, small incisions, and closed reductions provide greater comfort to the patient because of the shorter surgical time and lower morbidity. Therefore, minimally invasive surgical procedures, such as closed reductions with minimal accesses, can be indicated for selected IZAF cases. It is suggested that surgeons properly diagnose IZAF with adequate imaging tests to indicate the best treatment. It is still necessary to develop new studies on closed reductions to treat IZAF for scientific support.

\section{References}

Adam, A. A., Zhi, L., Bing, L. Z., \& Zhong Xing, W. U. (2012). Evaluation of treatment of zygomatic bone and zygomatic arch fractures: a retrospective study of 10 years. J Maxillofac Oral Surg, 11(2), 171-176.

Ahn, H. C., Youn, D. H., Choi, M. S. S., Chang, J. W., \& Lee, J. H. (2015). Wire or Hook Traction for Reducing Zygomatic Fracture. Arch Craniofac Surg, $16(3), 131-135$.

Camilleri, A. C., Gilhooly, M., \& Cooke, M. E. (2005). Stabilization of the unstable fractured zygomatic arch with a Kirschner wire. Br J Oral Maxillofac Surg, 43(2), 183-184.

Cavalcante, D. K. F., Veloso, S. R. M., Durão, M. A., Melo, V. C., Monteiro, G. Q. M., \& Porto, G. G. (2021). Do Helmet Use and Type Influence Facial Trauma Occurrence and Severity in Motorcyclists? A Systematic Review and Meta-analysis. J Oral Maxillofac Surg. https://doi.org/10.1016/j.joms.2021.02.028

Cheon, J. S., Seo, B. N., Yang, J. Y., \& Son, K. M. (2013). Clinical Follow-up on Sagittal Fracture at the Temporal Root of the Zygomatic Arch: Does It Need Open Reduction? Arch Plast Surg, 40(5), 546-552.

Cinal, H., Barin, E. Z., Çakmak, M. A., Kara, M., Yilmaz, K., \& Tan, O. (2019). Novel Surgical Technique for Repair of Zygomatic Fractures: Lever Technique. Plast Surg (Oakv), 27(2), 135-140.

Giran, G., Paré, A., Croisé, B., Koudougou, C., Mercier, J. M., Laure, B., Corre, P., \& Bertin, H. (2019). Radiographic evaluation of percutaneous transfacial wiring versus open internal fixation for surgical treatment of unstable zygomatic bone fractures. PLoS One, 14(8), e0220913.

Jang, J. W., Cho, J., \& Burm, J. S. (2021). Inferomedially impacted zygomatic fracture reduction by reverse vector using an intraoral approach with Kirschner wire. Arch Plast Surg, 48(1), 69-74.

Jardim, E. C. G., Junior, J. F. S., Melo, R. L. d., Mendonça, J. C. G. d., Faverani, L. P., Junior, I. R. G., \& Shinohara, E. H. (2013). Combinação de técnicas para tratamento cirúrgico de fratura do complexo zigomático-maxilar: relato de caso. Archives of Health Investigation, $2(3), 33-36$.

Ji, S. Y., Kim, S. S., Kim, M. H., \& Yang, W. S. (2016). Surgical Methods of Zygomaticomaxillary Complex Fracture. Arch Craniofac Surg, 17(4), 206-210.

Kim, J. S., Park, Y. J., Lee, Y. J., Kim, N. G., \& Lee, K. S. (2016). Reduction of Zygomatic Arch Isolated Fracture Using Ultra Sound and Needle Marking. Arch Craniofac Surg, 17(4), 198-201.

Korkmaz, Y. T., Coskun, U., Durmuslar, M. C., Zor, Z. F., Hocaoglu, T. P., \& Altintas, N. Y. (2016). Reduction of isolated zygomatic arch fractures using dental instrument: Report of 2 cases and review of the literature. J Pak Med Assoc, 66(3), 345-347.

Pereira, A. S., Shitsuka, D. M., Parreira, F. J., \& Shitsuka, R. (2018). Metodologia da Pesquisa Científica (1 ed.). Núcleo de Tecnologia Educacional da Universidade Federal de Santa Maria.

Prakasam, M., Dolas, R. S., Managutti, A., \& Deepashri, K. (2011). A modified temporal incision: an alternative approach to the zygomatic arch. J Maxillofac Oral Surg, 9(4), 428-433.

Ravi Raja Kumar, S., Venkata Raju, K., \& Sunanda, K. (2011). Stabilization of the Isolated Zygomatic Arch Fracture Using Foley's Balloon Catheter. J Maxillofac Oral Surg, 9(4), 407-409.

Rohit, Vishal, Prajapati, V. K., Shahi, A. K., Prakash, O., \& Ekram, S. (2021). Etiology, Modalities of Zygomaticomaxillary Complex Fracture, open reduction and fixation. J Clin Exp Dent, 13(3), e215-e220.

Starch-Jensen, T., Linnebjerg, L. B., \& Jensen, J. D. (2018). Treatment of Zygomatic Complex Fractures with Surgical or Nonsurgical Intervention: A Retrospective Study. Open Dent J, 12, 377-387.

Strong, E. B., \& Gary, C. (2017). Management of Zygomaticomaxillary Complex Fractures. Facial Plast Surg Clin North Am, $25(4), 547-562$.

Xie, L., Shao, Y., Hu, Y., Li, H., Gao, L., \& Hu, H. (2011). Modification of surgical technique in isolated zygomatic arch fracture repair: seven case studies. Int J Oral Maxillofac Surg, 38(10), 1096-1100.

Yamsani, B., Gaddipati, R., Vura, N., Ramisetti, S., \& Yamsani, R. (2016). Zygomaticomaxillary Complex Fractures: A Review of 101 Cases. J Maxillofac Oral Surg, 15(4), 417-424.

Yoon, H., Kim, J., Chung, S., \& Chung, Y. K. (2014). Effectiveness of Dual-Maneuver Using K-Wire and Dingman Elevator for the Reduction of Unstable Zygomatic Arch Fracture. Arch Craniofac Surg, 15(2), 59-62. 